\title{
STRATEGI PENINGKATAN KUALITAS PRODUK DALAM RANTAI PASOK KOMODITI PISANG DI PROVINSI BENGKULU
}

\section{STRATEGY FOR IMPROVING PRODUCT QUALITY IN THE SUPPLY CHAIN OF BANANA COMODITY IN BENGKULU PROVINCE}

\author{
Odi Andanu'*, Faqih Udin, dan Titi Candra Sunarti \\ ${ }^{1)}$ Departemen Teknologi Industri Pertanian, Fakultas Teknologi Pertanian, Institut Pertanian Bogor \\ Kampus IPB Dramaga, Bogor 16680, Indonesia \\ *Email : odi.andanu94@gmail.com
}

Makalah: Diterima 26 Januari 2021; Diperbaiki 14 Juni 2021; Disetujui 5 Juli 2021

\begin{abstract}
A well-being supply chain system will affect on the sustainability of the production and consumer's satisfaction. Consumer's need will be fulfilled if the served quality is in the accordance with consumer's expectations. This study aimed to identify banana supply chains, determine product quality attributes, and strategies for improving the quality of banana products. The methods used were Van der Vorst supply chain management framework, Quality Function Deployment (QFD), and Analytical Hierarchy Process (AHP). The research results exposed that banana supply chain consisted farmers, traders, industries, retailers, and consumers. The dominant quality factors on thise supply chain were the harvest planning $(0.24)$ and harvesting technique (0.19) for fresh bananas; the frying (0.28) and the packaging (0.20) for sale banana; the frying (0.28) and the packaging (0.17) for banana chips. Meanwhile, the quality attributes for fresh bananas were fruit maturity and damage level, for sale bananas were taste and texture, and for banana chips were taste and level of cracked chips. The proposed strategies to improve product quality in the banana comodity supply chain were an increase ability or skill in the production process for each actor (0.25), using standards in the product production process $(0.22)$, make a explicit contractual agreements between actors regarding product quality $(0.21)$, establish a structur farmer group institutions (0.13), optimizing local wisdom (0.10) and the government's role in assisting farmer and industrial development $(0.08)$.
\end{abstract}

Keywords: banana products, quality improvement, supply chain

\section{ABSTRAK}

Sistem rantai pasok yang baik akan berdampak pada keberlanjutan proses produksi dan kepuasan konsumen. Keinginan konsumen akan terpenuhi jika mutu yang diberikan sesuai dengan ekspektasi konsumen. Penelitian ini bertujuan untuk mengidentifikasi rantai pasok pisang, menentukan atribut mutu produk dan menentukan strategi peningkatan mutu produk berbasis pisang. Metode yang digunakan yakni kerangka manajemen rantai pasok Van der Vorst, Quality Function Deployment (QFD dan Analytical Hierarchy Process (AHP). Hasil penelitian ini adalah struktur rantai pasok pisang terdiri dari petani, pengepul, industri, retailer dan konsumen. Faktor mutu dominan yang berpengaruh terhadap rantai pasok komoditi pisang untuk pisang segar adalah perencanaan panen $(0,24)$ dan sortasi $(0,19)$, untuk sale pisang adalah penggorengan $(0,28)$ dan pengemasan $(0,20)$ dan untuk keripik pisang penggorengan $(0,28)$ dan pengemasan $(0,17)$. Sedangkan untuk atribut mutu buah pisang yakni tingkat kematangan buah dan tingkat kerusakan, atribut mutu sale pisang rasa dan tekstur, atribut mutu keripik pisang rasa dan tingkat keripik pecah. Strategi yang diusulkan untuk meningkatkan kualitas produk pada rantai pasok pisang adalah peningkatan kemampuan atau skill dalam proses produksi pada setiap aktor $(0,25)$, menggunakan standar dalam proses produksi produk $(0,22)$, memiliki kesepakatan kontrak antar aktor mengenai mutu produk yang jelas $(0,21)$, kelembagaan kelompok tani yang terstruktur $(0,13)$, optimalisasi kearifan lokal $(0,10)$ dan peran pemerintah dalam membantu pengembangan petani dan industri $(0,08)$.

Kata kunci: peningkatan kualitas, produk berbasis pisang, rantai pasok

\section{PENDAHULUAN}

Pisang merupakan jenis tumbuhan yang banyak ditemukan di Indonesia. Buah pisang mempunyai potensi yang tinggi dan dapat dikonsumsi maupun diolah menjadi produk olahan pangan dengan mempunyai nilai jual yang cukup tinggi. Produksi buah pisang di Indonesia pada tahun 2019 yakni 7.280.658 ton dengan luas lahan 105.801 ha, sedangkan produksi buah pisang di Provinsi Bengkulu yakni 24.313 ton dengan luas lahan 1.223 ha (BPS, 2019). Menurut Muhtasar (2005), Provinsi Bengkulu merupakan daerah sentra produksi buahbuahan, termasuk buah pisang. Salah satu jenis pisang yang terkenal adalah pisang Ambon Curup. Pisang ini dikenal karena rasanya yang manis, daging buahnya yang halus dan lunak, serta bentuk buahnya yang khas. 
Pisang Ambon Curup salah satu produk pertanian unggulan di Provinsi Bengkulu yang telah memiliki sertifikat bebas dari zat berbahaya, sehingga memiliki potensi untuk dikembangkan atau dijadikan produk olahan berbasis buah pisang. Pada saat ini buah pisang hanya diolah menjadi keripik dan sale pisang, dikarenakan permintaan konsumen yang tinggi akan produk tesebut dan proses pengolahan yang tergolong mudah menyebabkan banyak industri skala kecil yang mengolah buah pisang. Belum optimalnya program dari pemerintah menyebabkan UKM sulit berkembang dan bersaing di pasar yang lebih besar.

Kabupaten Kepahiang merupakan salah satu kabupaten yang banyak terdapat industri rumah tangga yang mengolah buah pisang. Dengan jumlah industri rumah tangga terbanyak berada di Desa Tebat Monok yang sampai saat ini telah mencapai 10 industri sehingga menjadikan desa tersebut sebagai pusat oleh-oleh bagi wisatawan dari dalam dan luar Kabupaten Kepahiang. Faktor-faktor yang mendorong masyarakat di Desa Tebat Monok untuk mengolah buah pisang antara lain karena tersedianya bahan baku pisang yang banyak, keinginan untuk menambah penghasilan, lokasi desa yang strategis di jalan lintas Kepahiang-Bengkulu dan usaha ini dapat menciptakan lapangan kerja.

Buah pisang mempunyai daya guna yang luas sebagai bahan baku industri pangan dan non-pangan juga sebagai konsumsi rumah tangga (Simin, 2014). Komoditas pertanian pada umumnya berupa bahan mentah yang mudah rusak (perishable) sehingga perlu langsung dikonsumsi atau diolah oleh agroindustri guna menambah nilai dari komoditas pertanian dan menyempurnakan hasil pertanian (Pratiwi, 2015). Keberlanjutan produksi suatu industri berkaitan erat dengan sistem rantai pasok. Rantai pasok mencakup semua operasi yang menghubungkan pemasok disatu sisi dan pelanggan di sisi lain (Kozarević, 2015). Peningkatan efisiensi, salah satunya dapat dilakukan dengan integrasi kegiatan rantai pasok perusahaan, agar tidak terjadi kesulitan dalam proses perencanaan operasional rantai pasok. Konsep manajemen rantai pasok (Supply Chain Management atau SCM) mampu mengintegrasikan pengelolaan berbagai fungsi manajemen dalam suatu hubungan antar-organisasi sehingga membentuk satu sistem yang terpadu dan saling mendukung (Mutakin dan Hubeis, 2011).

Manajemen rantai pasok agroindustri memiliki model yang berbeda dari manufaktur konvensional, yaitu bahan baku dan produk yang mudah rusak, aktivitas bisnis tergantung pada kondisi musiman, ukuran dan kualitas bahan baku yang bervariasi, penanganan yang banyak dan sulit (Marimin, 2010). Ray (2010) menyatakan bahwa pendistribusian produk buah segar atau sayuran memiliki risiko kerusakan yang dampaknya akan ditanggung oleh pihak retailer atau tahap akhir dalam jaringan rantai pasok. Produk yang berupa fresh product berpeluang mengalami penurunan kualitas dalam setiap tahap dalam jaringan rantai pasok. Rantai pasok produk berbasis buah pisang di Provinsi Bengkulu masih belum optimal sehingga menyebabkan produktifitas produksi produk berbasis pisang masih rendah. Pada tahun 2019 tercatat produktifitas produksi pisang di Provinsi Bengkulu sebesar 52 ton/ha, jauh lebih rendah jika dibandingkan dengan Provinsi Lampung yang mencapai 104 ton/ha. Penyediaan bahan baku dari para petani sampai ke proses pemasaran masih banyak kendala yang dihadapi oleh industri. Dalam rantai pasok ada empat elemen yang secara positif terkait dengan kualitas dan keamanan pangan yaitu kepercayaan, strategi kerjasama, komitmen, dan kualitas informasi (Ding et al., 2014).

Dalam beberapa tahun terakhir, kualitas produk semakin mendapat perhatian oleh konsumen. Terlebih lagi di beberapa industri setelah harga produk, kualitas telah menjadi faktor terpenting kedua yang mempengaruhi keputusan pembelian konsumen. Peningkatan kualitas produk adalah faktor penting bagi perusahaan untuk mendapatkan dan mempertahankan keunggulan kompetitif (Zaim et al., 2014). Oleh karena itu, banyak industri sekarang mengadopsi peningkatan kualitas produk sebagai alat kompetitif yang kuat dalam memenuhi tingkat harapan konsumen (He et al., 2016). Ketika kualitas produk ditingkatkan, konsumen menghargai produk lebih tinggi, yang mengarah pada peningkatan harga referensi (He et al., 2016). Karena harga referensi dan kualitas referensi memiliki efek signifikan pada perilaku pembelian konsumen, efek referensi ini harus dipertimbangkan dalam manajemen kualitas persediaan sehingga memungkinkan pemilik usaha untuk membuat keputusan yang lebih baik mengenai peningkatan kualitas. Di sisi lain, kualitas produk penting bagi konsumen yang siap membayar harga tinggi untuk mendapatkan produk berkualitas tinggi sebagai imbalannya. Tetapi kualitas produk yang lebih tinggi kadang-kadang menyebabkan beban biaya tambahan bagi produsen karena biaya produksi yang lebih tinggi, ini memungkinan harga produk yang tinggi.

Hubungan rantai pasok memiliki dampak penting pada kualitas produk yang dihasilkan. Ada dua faktor kunci untuk meningkatkan hubungan yang harmonis dalam rantai pasok produk pangan yakni kepercayaan dan komunikasi para pelakunya (Liu, 2018). Manajemen layanan konsumen telah menjadi isu strategis dalam logistik dan manajemen rantai pasok. Perusahaan dapat meningkatkan kepuasan konsumen dan mendapatkan pangsa pasar dengan meningkatkan kinerja logistik dan rantai pasok (Ayăg, 2013).

Kualitas produk berbasis pisang di Provinsi Bengkulu belum optimal disebabkan oleh beberapa faktor diantaranya yaitu proses produksi yang belum 
memenuhi standar dan kualitas bahan baku yang fluktuatif sehingga menghasilkan produk yang kurang kompetitif dan kurangnya pangsa pasar. Cara populer dan terbukti untuk menentukan apa yang diinginkan pelanggan dan bagaimana menyalurkan keinginan mereka ke dalam desain produk adalah melalui Quality Function Deployment (QFD) (Zaim et al., 2014). QFD adalah sistem kualitas komprehensif yang menargetkan kepuasan pelanggan. Tujuan penerapan QFD adalah untuk memasukkan kehendak pelanggan ke dalam berbagai tahap siklus produksi atau pengembangan sistem dan juga untuk mencapai kualitas yang diminta oleh konsumen (Aya, 2012). Kualitas produk berbasis pisang sangat penting ditingkatkan untuk menarik minat konsumen dan menjangkau pangsa pasar yang lebih luas. Oleh karena itu, diperlukan suatu kajian mengenai perencanaan peningkatan kualitas produk dalam rantai pasok komoditi berbasis buah pisang. Tujuan dari penelitian ini menentukan karakteristik dan struktur mutu rantai pasok komoditi berbasis pisang, mendesain faktor-faktor mutu dominan berpengaruh terhadap rantai pasok komoditi pisang dan menentukan strategi peningkatan kualitas produk.

\section{METODE PENELITIAN}

\section{Kerangka Pemikiran}

Sistem rantai pasok yang baik akan memberikan dampak pada keberlanjutan proses produksi dan kepuasan konsumen. Sistem rantai pasok meliputi proses pengadaan, perencanaan dan pengendalian, operasi atau produksi yang berkaintan dengan pengendalian kualitas dan proses distribusi. Kinerja rantai pasok dari sisi kualitas meliputi pengendalian kualitas disepanjang rantai pasok untuk mengurangi penurunan kualitas. Produk berbasis buah pisang yang berkualitas akan terpenuhi jika mutu yang diberikan sesuai dengan keinginan konsumen. Untuk memenuhi kepuasan tersebut, perlu diketahui kualitas mutu melalui harapan pelanggan akan atribut mutu. Atribut mutu harapan pelanggan ini akan menjadi acuan bagi pihak yang terlibat di dalam pengolahan untuk dapat menyesuaikan aktifitasnya. Namun, keberhasilan aktivitas ini perlu memperhatikan faktor-faktor yang dominan mempengaruhi mutu, teknik melakukan proses, sumber bahan baku dan manajemen rantai pasok.

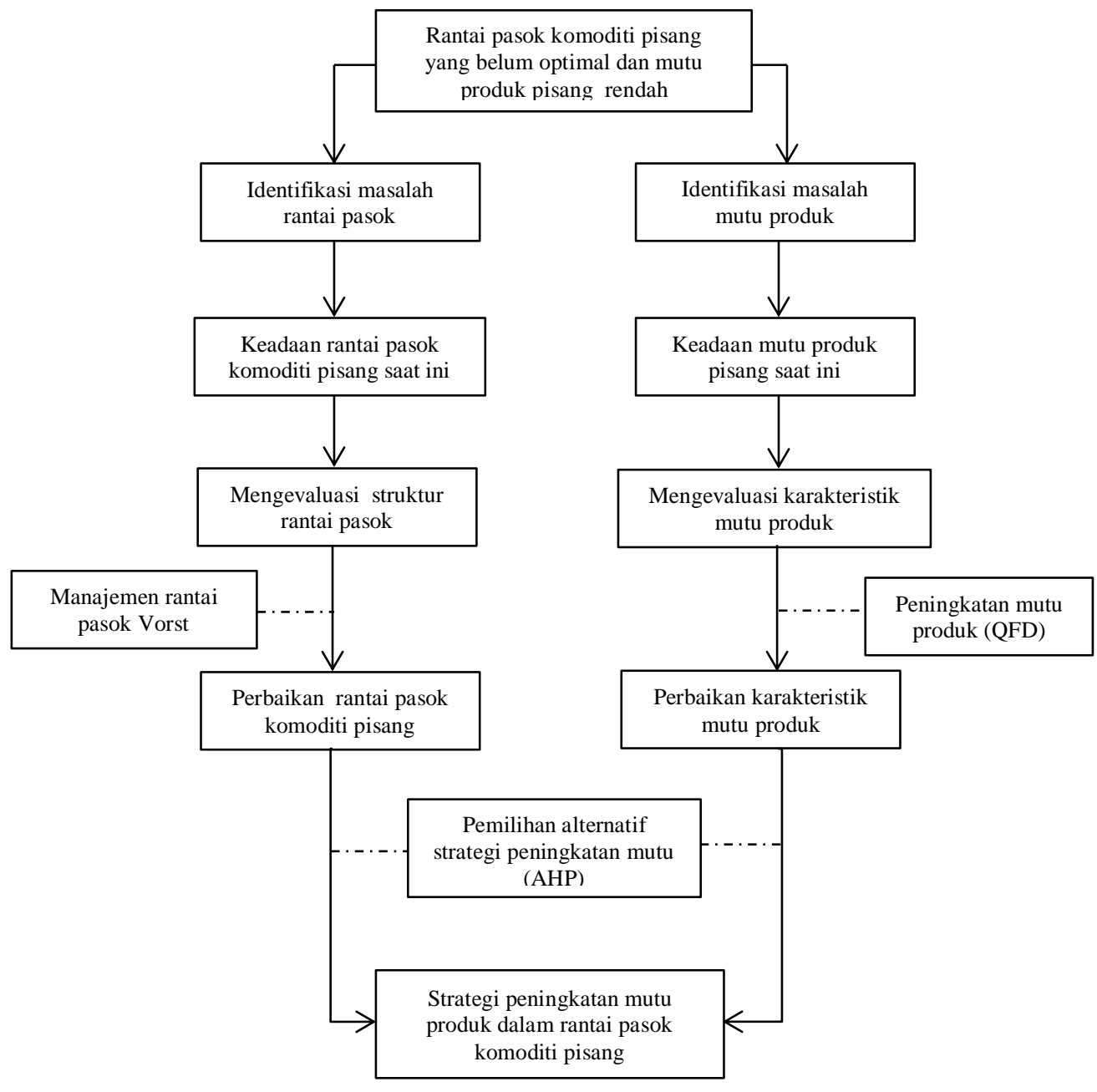

Gambar 1. Kerangka pemikiran penelitian 


\section{Teknik Pengumpulan Data}

Data yang digunakan dalam penelitian ini adalah data primer dan data sekunder. Data primer diperoleh dari observasi lapang, wawancara, dan diskusi menggunakan daftar pertanyaan kepada petani, pengepul, industri olahan pisang, retailer dan pakar. Data yang diambil meliputi identitas responden meliputi jenis usaha dan lama pengalaman dibidangnya, keadaan usaha petani pisang secara umum, kondisi rantai pasok di setiap anggota rantai pasok, hubungan antar rantai pasok secara keseluruhan, dan opini pakar yang terdiri dari masingmasing aktor, akademisi dan pemerintahan. Data sekunder diperoleh dan dikumpulkan berdasarkan hasil analisis deskriptif berupa studi pustaka, hasil penelitan sebelumnya, jurnal ilmiah, dinas/instansi terkait kepentingan penelitian, dan industri yang diteliti.

\section{Teknik Penentuan Sampel}

Teknik penentuan sampel pengamatan rantai pasok komoditas pisang melalui jenis investigasi kausalitas. Metode kuantitatif melalui pengumpulan data primer menggunakan kuesioner. Semua data dikumpulkan langsung dari responden yang terlibat di dalam rantai pasok. Teknik penentuan sampel menggunakan teknik purposive sampling dilakukan mengikuti kriteria seperti petani dan pemilik lahan pisang, pengumpul sementara (middle man), pengumpul di tingkat kota, industri olahan pisang, retailer produk olahan pisang dan konsumen produk olahan pisang.

\section{Lokasi dan Waktu Penelitian}

Penelitian ini dilakukan di sentra penghasil buah pisang dan industri pengolah pisang Kabupaten Rejang Lebong dan Kabupaten Kepahiang Provinsi Bengkulu. Pada bulan Desember 2019 hingga Maret 2020.

\section{Metode Analisis}

Identifikasi struktur rantai pasok dianalisis melalui observasi lapang dan wawancara kepada setiap anggota rantai pasok. Selanjutnya, identifikasi rantai pasok dengan kerangka manajemen rantaipasokan Van der Vorst (2006). Rantai pasok dianalisis dengan menggunakan metode deskriptif dan output dari analisis ini adalah gambaran umum kondisi obyektif rantai pasok buah pisang. Hasil analisis tersebut dilanjutkan dengan penentuan atribut mutu produk di sepanjang rantai pasok menggunakan Quality Function Deployment (QFD) untuk mendapatkan atribut mutu produk berbasis pisang dengan mengubah permintaan atau persyaratan pelanggan menjadi karakteristik teknis dari produk lebih baik. Penentuan strategi peningkatan kualitas produk dilakukan pembobotan menggunakan Analytical Hierarchy Process (AHP). Prinsip kerja AHP adalah penyederhanaan suatu persoalan kompleks yang tidak terstruktur, strategik dan dinamik menjadi sebuah bagian-bagian yang tertata dalam suatu hierarki (Marimin dan Maghfiroh, 2011). Dari hasil AHP maka disusunlah strategi yang dapat digunakan untuk peningkatkan kualitas produk yang ada di rantai pasok komoditi pisang.

\section{HASIL DAN PEMBAHASAN}

\section{Analisis Rantai Pasok}

Struktur jaringan rantai pasok tidak hanya terdiri dari pabrik pengolahan, tetapi juga terdiri dari transportir, pedagang besar, toko ritel dan konsumen akhir (Chopra dan Meindl, 2013). Rantai pasok komoditi pisang terbentuk karena adanya integrasi dan koordinasi antar anggota di dalamnya untuk memenuhi kebutuhan konsumen. Secara umum industri pengolahan pisang memperoleh bahan baku melalui penyalur atau pengepul. Sebelum itu, terjadi aktivitas perawatan dan penanganan lahan perkebunan untuk menghasilkan bahan baku. Bahan baku yang diperoleh selanjutnya diolah di industri olahan pisang dengan berbagai metode pengolahan untuk menghasilkan berbagai jenis produk yang disesuaikan permintaan konsumen. Produk pisang yang dihasilkan selanjutnya dipasarkan kepada konsumen melalui beberapa cara, seperti dijual sendiri oleh industri dan retailer. Secara umum, pola rantai pasok pisang dapat dilihat pada Gambar 2.

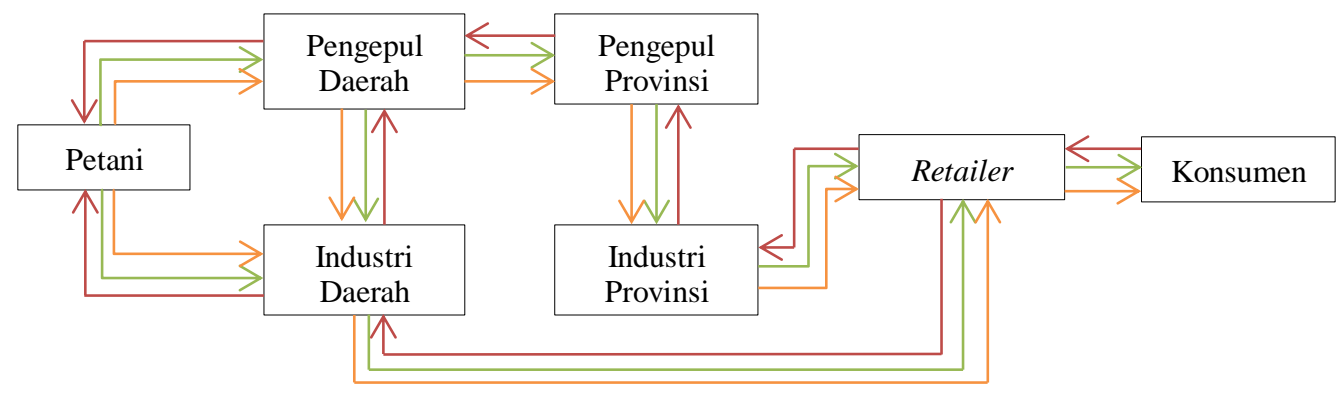

Ket :

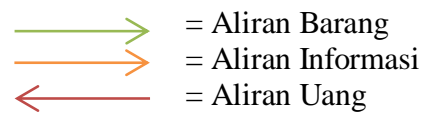

Gambar 2. Struktur rantai pasok pisang 


\section{Anggota Rantai dan Aliran Komoditas}

Struktur rantai pasok komoditas pisang terdiri atas berbagai faktor. Menurut Widiastuti (2011) aktor yang terlibat pada rantai pasok pisang ambon curup yakni petani, pengumpul, pedagang dan konsumen dimana hasil penelitian ini tidak mengamati industri olahan pisang. Diawali dengan sumber bahan baku, yaitu buah pisang segar yang berasal dari berbagai sumber pemasok atau petani, proses pengolahan yang dilakukan oleh industri untuk diolah menjadi berbagai produk pisang, pemasaran produk yang dilakukan oleh retailer serta konsumen sebagai end user dari aliran rantai pasok komoditas pisang. Aliran komoditas buah pisang dapat dilihat pada Gambar 2. Aliran buah pisang pada model rantai komoditas pasok pisang dapat digambarkan dalam beberapa struktur rantai, yaitu :

1. Petani - Industri - Konsumen

2. Petani - Pengepul - Industri - Konsumen

3. Petani - Pengepul - Industri - Retailer Konsumen

4. Petani - Pengepul Daerah - Pengepul Provinsi Industri - Konsumen

5. Petani - Pengepul Daerah - Pengepul Provinsi Industri - Retailer - Konsumen

\section{Atribut Mutu Buah Pisang Segar}

Prioritas atribut mutu pisang segar adalah tingkat kematangan buah pisang. Pematangan buah adalah proses transformasi organ dari mentah menjadi tahap matang yang dapat dimakan dengan perpaduan warna, rasa, aroma dan tekstur yang menarik. Pada buah klimakterik seperti pisang perubahan tersebut terjadi sangat cepat karena dua proses fisik yang penting yaitu produksi etilen dan tingkat respirasi mencapai puncaknya setelah dipanen (Murmu dan Mishra, 2016). Tingkat kematangan buah yang optimum, yaitu pada saat buah telah berwarna hijau tua dan setiap buah telah berisi dari bagian sisir pangkal hingga sisir yang bagian ujung. Menurut SNI pisang, ukuran jari buah pisang yang paling bagus atau grade 1 yakni sebesar $20 \mathrm{~cm}$ dan paling rendah atau grade 4 yakni sebesar $5 \mathrm{~cm}$. Tingkat kematangan buah yang tepat juga sangat berpengaruh terhadap proses pengolahan dan hasil produk. Jika proses pengolahan menggunakan buah yang memiliki tingkat kematangan yang kurang maka produk yang dihasilkan juga memiliki kualitas yang rendah. Susunan prioritas atribut mutu buah pisang segar dapat dilihat pada Tabel 1 dan direpresentasikan dalam Gambar 3 .

Tabel 1. Atribut mutu buah pisang

\begin{tabular}{clcc}
\hline No & \multicolumn{1}{c}{ Atribut } & Prioritas & Prioritas Dalam QFD \\
\hline 1 & Persyaratan panen & 4 & 4 \\
2 & Tingkat kematangan & 1 & 7 \\
3 & Keseragaman bentuk & 6 & 2 \\
4 & Tingkat kerusakan & 2 & 6 \\
5 & Tangkai buah & 5 & 3 \\
6 & Tampilan segar & 3 & 5 \\
7 & Proses pengiriman & 7 & 1 \\
\hline
\end{tabular}

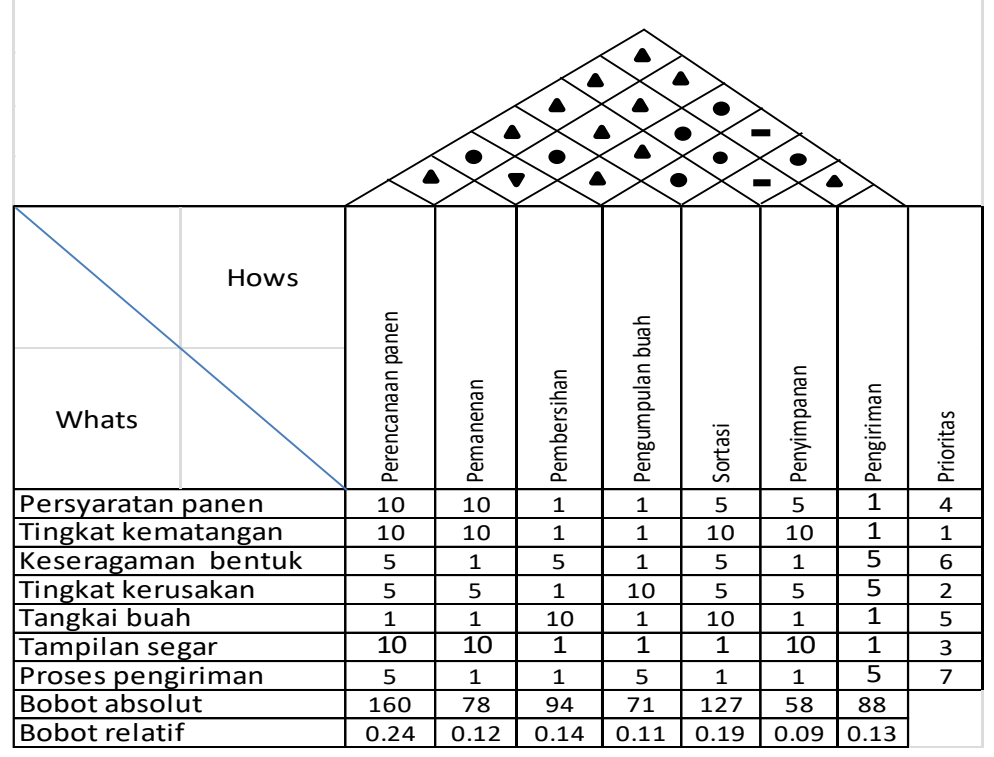

Keterangan : Hubungan antara persyaratan pelanggan dengan proses :

$$
\begin{aligned}
& 10=\text { Kuat } \quad 5=\text { Sedang } \quad 1=\text { Lemah } \\
& \text { Hubungan antara proses : } \\
& \text { - Mempengaruhi - Dipengaruhi } \\
& \text { - Saling mempengaruhi } \text { - Tidak ada hubungan }
\end{aligned}
$$

Gambar 3. Rumah kualitas (QFD I) pisang dengan tahapan proses 
Rangkaian tahapan proses yang paling mempengaruhi atribut mutu adalah perencanaan panen, seperti terlihat pada Gambar 3. Proses panen yang dilakukan petani saat ini hanya berdasarkan pengamatan langsung terhadap buah pisang. Sehingga menghasilkan buah pisang yang memiliki tingkat kematangan berbeda-beda. Perencanaan panen yang tepat akan menghasilkan buah dengan tingkat kematangan yang optimum. Perencanaan panen meliputi kegiatan menghitung waktu yang tepat kapan buah pisang telah siap dipanen karena kegiatan ini sangat berpengaruh terhadap tingkat kematangan buah. Bila terlalu cepat maka buah pisang yang dihasilkan masih memiliki tingkat kematangan yang rendah atau mudah, bila terlalu lama maka buah pisang akan terlalu matang. Buah pisang yang terlalu matang akan sangat berdampak buruk pada proses pengiriman buah dengan jarak yang jauh dan memakan waktu yang lama. Menurut Dafri et al. (2018), proses pematangan yang cepat akan mempersulit penanganan pasca panen seperti penyortiran, penyimpanan serta pendistribusian untuk diolah.

Atribut mutu lain yang mempengaruhi yakni tingkat kerusakan buah pisang. Menurut Dafri et al. (2018), buah pisang yang mengalami kerusakan akan menghasilkan gas etilen yang lebih banyak dari pada buah pisang yang normal sehingga mempengaruhi pematangan buah pisang lain yang ada disekitarnya. Buah pisang termasuk jenis buah klimaterik dimana setelah dipanen buah pisang masih mengalami proses pematangan buah, maka dari itu tingkat kerusakan buah sangat berpengaruh terhadap mutu produk. Tingkat konsumsi oksigen $\left(\mathrm{O}_{2}\right)$, perubahan karbon dioksida $\left(\mathrm{CO}_{2}\right)$, dan produksi etilen mencapai nilai puncak setelah dipanen. Proses ini juga akan menghasilkan kematangan maksimal, rasa enak, aroma dan kualitas makan buah yang maksimal. Penuaan terjadi setelah puncak klimakterik, dimana buah membusuk secara bertahap (Murmu dan Mishra, 2016). Semakin besar tingkat kerusakan, semakin cepat juga proses penurunan mutu dari buah, maka risiko ini sebaiknya dimimalisir sebaik mungkin.

Proses yang paling berpengaruh terhadap tingkat kerusakan yakni pada proses pengumpulan buah, setelah buah pisang dipotong dari tangkainya dan pada proses pengiriman. Pengumpulan buah yang telah dipanen dilakukan di kebun dimana untuk memudahkan proses pengangkutan atau pengiriman. Buah ditumpuk dan tidak diberi alas hal ini dapat melukai kulit buah pisang yang bersentuhan dengan benda-benda yang keras seperti kayu, batu dan sesama buah pisang. Proses pengiriman buah juga rawan terjadi kerusakan, buah pisang ditumpuk tanpa diberi pemisah antara buah pisang, jika terjadi goncangan maka ini dapat membuat buah pisang memar dan rusak. Menurut Novitasari (2013), buahbuahan mudah mengalami kerusakan mekanis, fisiologis, kimiawi dan mikrobiologis dimana tingkat kerusakan buah tersebut dapat mencapai 30-50\% sesuai dengan komoditasnya.

Atribut mutu yang berpengaruh selanjutnya yakni tampilan buah yang segar. Buah yang memiliki tampilan yang baik akan memiliki tingkat permintaan yang baik juga. Kesegaran buah yang matang akan memiliki banyak pilihan bagi industri untuk dijual langsung atau diolah menjadi produk lain. Buah pisang yang bagus dijual dalam bentuk buah segar dimana satu sisir bisa dijual dengan harga Rp 20.000. Buah pisang yang memiliki tampilan yang tidak bagus diolah menjadi produk lain yakni dijadikan keripik pisang dan sale pisang.

Tahapan proses yang memperngaruhi atribut mutu produk adalah proses sortasi. Proses sortasi dilakukan untuk membersihkan bagian-bagian yang tidak diperlukan dan camaran yang dapat merusak buah pisang. Bagian yang tidak diperlukan seperti tangkai buah, bagian ini harus dibersihkan agar mempermudah proses pengiriman. Tangkai buah juga berpengaruh terhadap volume dan berat pisang maka dari itu tangkai buah harus dibersihkan. Proses sortasi yang dilakukan oleh petani masih sedikit hanya sebatas pada pemotongan tangkai dan mengelompokkan buah yang besar dan kecil untuk mempermudah proses pengiriman dan penjualan ke pengepul dan industri. Menurut Wiharja dan Harjoko (2014), dalam meningkatkan mutu buah pisang perlu dilakukan proses sortasi, tetapi saat ini sortasi mutu pisang masih dilakukan secara manual sehingga menghasilkan keragaman mutu yang kurang baik.

Buah pisang yang telah selesai dipanen dan disortasi oleh petani selanjutnya dikirim ke pembeli. Pembeli disini ada dua aktor yakni pengepul dan industri. Jika dijual ke pengepul, petani tidak perlu mengirimkan buah pisang dengan jarak yang terlalu jauh, dikarenakan hampir disetiap desa ada pengepul yang membeli buah pisang. Sedangkan petani yang memiliki jumlah produksi buah pisang yang besar dapat mengirim buah pisangnya langsung ke industri. Hal ini disebabkan oleh biaya kirim dan harga yang ditawarkan dari masing-masing aktor. Pengiriman buah pisang dari pengepul ke industri menggunakan mobil pick up sedangkan untuk pengepul yang mengirimkan buah pisang ke pengepul di laur daerah menggunakan truk. Dalam sekali pengiriman pengepul dapat mengirim pisang sebanyak lebih dari 4 ton. Buah pisang yang dikirim sudah matang tetapi tetap berwarna hijau agar pada saat sampai di lokasi buah pisang telah berganti warna menjadi kuning. Selain itu penyusunan buah di dalam truk hanya ditumpuk tanpa pemisah hal ini sangat rawan benturan dan mengakibatkan buah pisang yang paling bawah mengalami kerusakan.

\section{Atribut Mutu Keripik Pisang}

Produk keripik pisang merupakan salah satu dari banyaknya produk olahan yang berbahan buah pisang. Tidak sedikit masyarakat yang menyukai 
keripik pisang sebagai cemilan. Dalam memenuhi keinginan konsumen keripik pisang, diperlukan strategi yang dapat meningkatkan kualitas produk. Salah satu cara yang dapat digunakan yakni dengan menyusun prioritas atribut mutu, selanjutnya ditentukan prioritas dari masing-masing atribut. Susunan prioritas atribut mutu keripik pisang dapat dilihat pada Tabel 2 dan direpresentasikan dalam Gambar 4.

Tabel 2. Atribut mutu keripik pisang

\begin{tabular}{clcc}
\hline No & \multicolumn{1}{c}{ Atribut } & Prioritas & Prioritas \\
\hline 1 & Rasa yang enak & 1 & 7 \\
2 & Tidak ada yang pecah & 2 & 6 \\
3 & Kemasan bagus & 6 & 2 \\
4 & Tidak mudah tengik & 2 & 6 \\
5 & Tidak berminyak & 5 & 3 \\
6 & Warna yang alami & 7 & 1 \\
7 & Tidak keras & 3 & 5 \\
8 & Umur simpan produk panjang & 4 & 4 \\
\hline
\end{tabular}

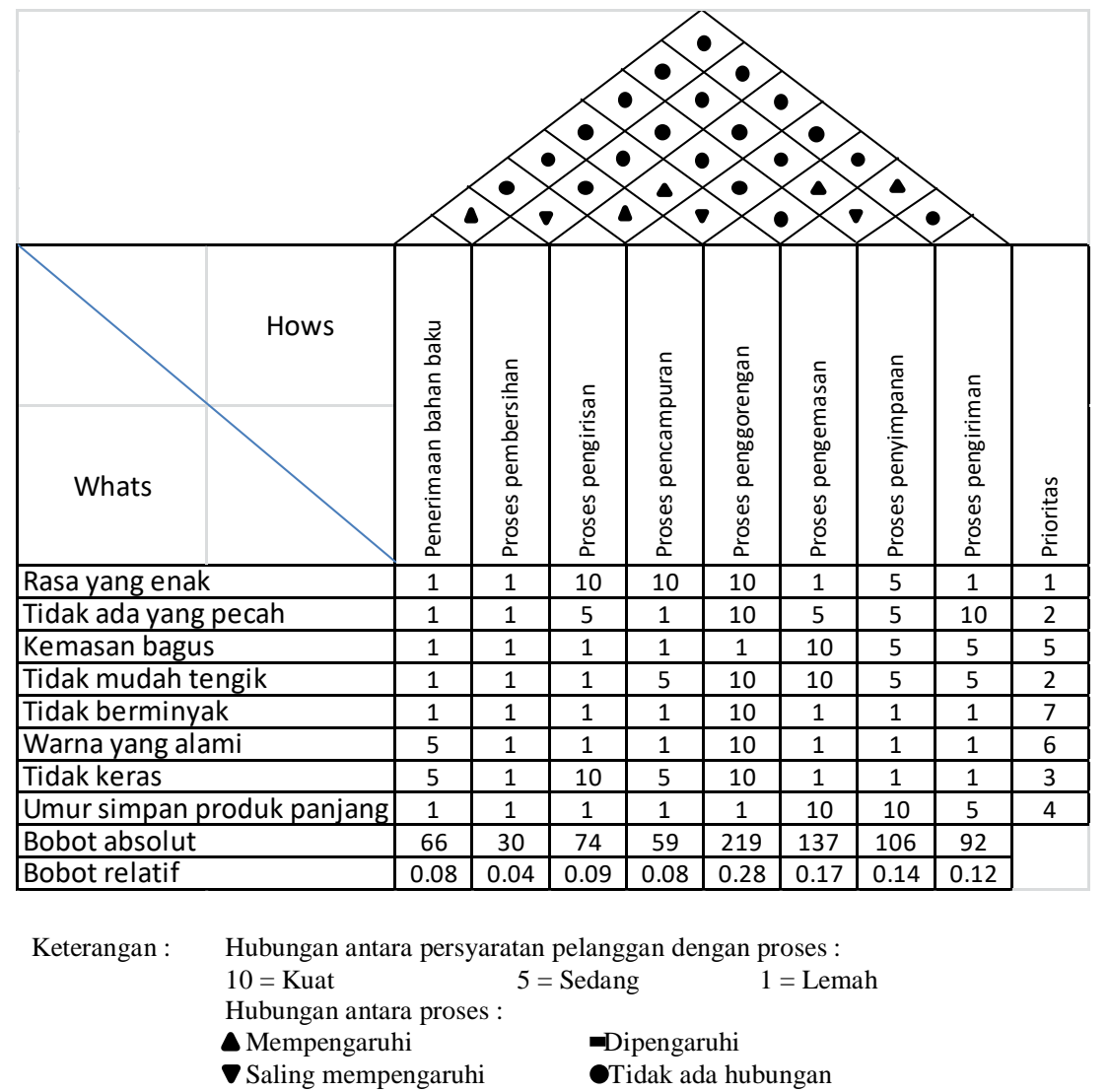

Gambar 4. Rumah kualitas (QFD II) keripik pisang dengan tahapan proses

Pada Tabel 2, atribut mutu yang paling diprioritaskan adalah dari sisi rasa produk yang enak dikonsumsi. Menurut Agatha et al. (2020), atribut dengan persentasi tertinggi yang paling mempengaruhi konsumen dalam memilih keripik pisang adalah atribut rasa. Tidak dipungkiri setiap konsumen pada saat membeli suatu produk hal yang pertama yang diinginkan atau diharapkan adalah dari sisi rasa produknya. Jika produk memiliki rasa yang baik menurut konsumen ini akan menjadi awal yang baik dan konsumen pun akan berminat untuk membeli produk tersebut di kemudian hari.
Tahapan proses yang paling berpengaruh terhadap atribut rasa produk yakni tahapan penggorengan, pencampuran dan pengirisan seperti pada Gambar 4. Pada tahapan proses penggorengan pisang yang telah diiris menjadi proses yang paling menentukan dalam sisi atribut rasa. Menurut Nurainy et al. (2013), proses penggorengan akan mengahasilkan kerenyahan pada keripik pisang. Kerenyahan merupakan parameter yang digunakan untuk menilai tekstur dari produk makanan kering. Jika irisan pisang terlalu lama digoreng maka keripik pisang yang dihasilkan akan menjadi terlalu garing 
dan berwarna coklat. Sebaliknya jika terlalu singkat maka irisan pisang tidak garing dan keras, hal itu dapat merusak atribut rasa keripik pisang.

Tahapan proses pencampuran juga berpengaruh terhadap atribut rasa. Bahan campuran yang digunakan dalam produksi keripik pisang yang saat ini digunakan adalah gula dan garam. Bahan tambahan ini diperlukan secukupnya agar produk yang dihasilkan tidak terlalu asin dan tidak telalu manis. Selanjutnya tahapan proses pengirisan juga berpengaruh terhadap atribut rasa. Jika irisan terlalu tebal maka produk yang dihasilkan menjadi keras pada saat dikonsumsi, sebaliknya jika terlalu tipis maka keripik pisang akan mudah pecah. Hal ini dapat menurunkan estetika produk jika dilihat oleh konsumen.

Atribut mutu selanjutnya yakni keripik tidak pecah dan tidak tengik. Kedua atribut mutu ini juga sangat diperhatikan oleh konsumen. Pada saat membeli keripik pisang konsumen akan memilih produk yang memiliki sedikit irisan yang pecah. Banyaknya bagian irisan keripik yang pecah disebabkan oleh irisan yang terlalu tipis, sehingga pada saat proses pengemasan dan pengiriman irisan yang tipis tersebut tidak bertahan tertahan terhadap benturan dan guncangan. Atribut mutu lainnya yakni aroma keripik yang tidak tengik ini juga menjadi atribut mutu yang diperhatikan oleh konsumen. Aroma yang tengik menandakan keripik pisang telah mengalami penyimpangan mutu. Salah satu penyebab aroma tengik adalah adanya bagian kemasan yang tidak tertutup rapat atau adanya kebocoran di kemasan sehingga udara dari luar masuk ke kemasan produk dan merusak produk. Menurut Susanti et al. (2020), keripik pisang mengandung kadar air yang sangat rendah dan mengandung kadar lemak yang tinggi sehingga menyebabkan keripik pisang mudah mengalami ketengikan apabila kontak langsung dengan oksigen atau cahaya.

Tahapan proses yang berpengaruh terhadap atribut mutu keripik yang tidak pecah dan tidak tengik yakni pada proses pengiriman dan pengemasan produk. Pemilihan jenis kemasan yang tepat sesuai sifat produk dapat menjaga kadar air dan mutu produk karena dapat menghambat uap air, cahaya dan udara (Susanti et al., 2020). Pada tahapan proses pengiriman produk ke retailer produk dikirim menggunakan kendaraan roda dua dan produk disusun langsung tanpa ada alas dan pemisah antar produk. Jika disusun terlalu banyak dan terjadi goncangan pada saat pengiriman dapat menyebabkan keripik pisang menjadi pecah. Selanjutnya tahapan pengemasan produk menggunakan alat plastic sealer. Diperlukan kehati-hatian pada proses pengemasan agar semua bagian dapat tertutup rapat dan tidak ada udara yang masuk ke dalam ruangan kemasan.

\section{Atribut Mutu Sale Pisang}

Sale pisang adalah makanan semi basah dibuat dari pisang matang dengan cara pengeringan dan atau pengasapan dengan atau tanpa penambahan pengawet. Sale pisang juga termasuk salah satu dari produk bebasis buah pisang, yang menjadi pembeda dari keripik pisang yakni bahan baku dan proses pembuatan. Bahan baku yang digunakan di keripik pisang menggunakan buah pisang yang telah tua tapi belum matang, sedangkan sale pisang menggunakan buah pisang yang telah tua dan matang sempurna. Susunan prioritas atribut mutu sale pisang dapat dilihat pada Tabel 3 dan direpresentasikan dalam Gambar 5.

Atribut mutu prioritas yang pertama adalah rasa dari sale pisang. Rasa sale pisang manis dan sedikit lembek yang mana sale pisang tidak telalu garing. Hal ini disebabkan bahan baku sale pisang menggunakan buah pisang yang telah matang sempurna. Menurut Prabawati et al. (2008), pada dasarnya semua buah pisang dapat diolah menjadi sale, hanya saja tidak semua jenis pisang menghasilkan dengan rasa yang enak. Sale yang enak terbuat dari pisang Ambon, Kepok, Siem, Raja Bulu, dan Emas.

Tingkat kematangan buah pisang yang tepat untuk diolah menjadi sale adalah buah dengan tingkat kematangan penuh, yaitu buah pada tingkat kematangan siap untuk dikonsumsi segar. Di samping itu pisang dipilih yang bebas dari kerusakan mekanis maupun mikrobiologis. Buah pisang yang menderita kerusakan fisik, pada bagian yang terkena kerusakan tersebut, daging buahnya tidak dapat menjadi matang dan teksturnya tetap keras. Karena tetap mentah, kandungan terbanyak adalah pati bukan gula. Bila daging buah pada kondisi tersebut dikeringkan, maka sale pisang yang dihasilkan akan tetap berwarna putih. Dengan demikian penampakan sale tidak mulus, terdapat warna kuning kecoklatan dan putih kecoklatan.

Tabel 3. Atribut mutu sale pisang

\begin{tabular}{clcc}
\hline No & \multicolumn{1}{c}{ Atribut } & Prioritas & Prioritas Dalam QFD \\
\hline 1 & Rasa yang enak & 1 & 8 \\
2 & Ukuran yang seragam & 4 & 3 \\
3 & Kemasan bagus & 7 & 1 \\
4 & Tidak mudah tengik & 3 & 5 \\
5 & Tidak berminyak & 5 & 4 \\
6 & Warna yang alami & 6 & 2 \\
7 & Tekstur lembut & 2 & 7 \\
8 & Umur simpan produk panjang & 8 & 6 \\
\hline
\end{tabular}




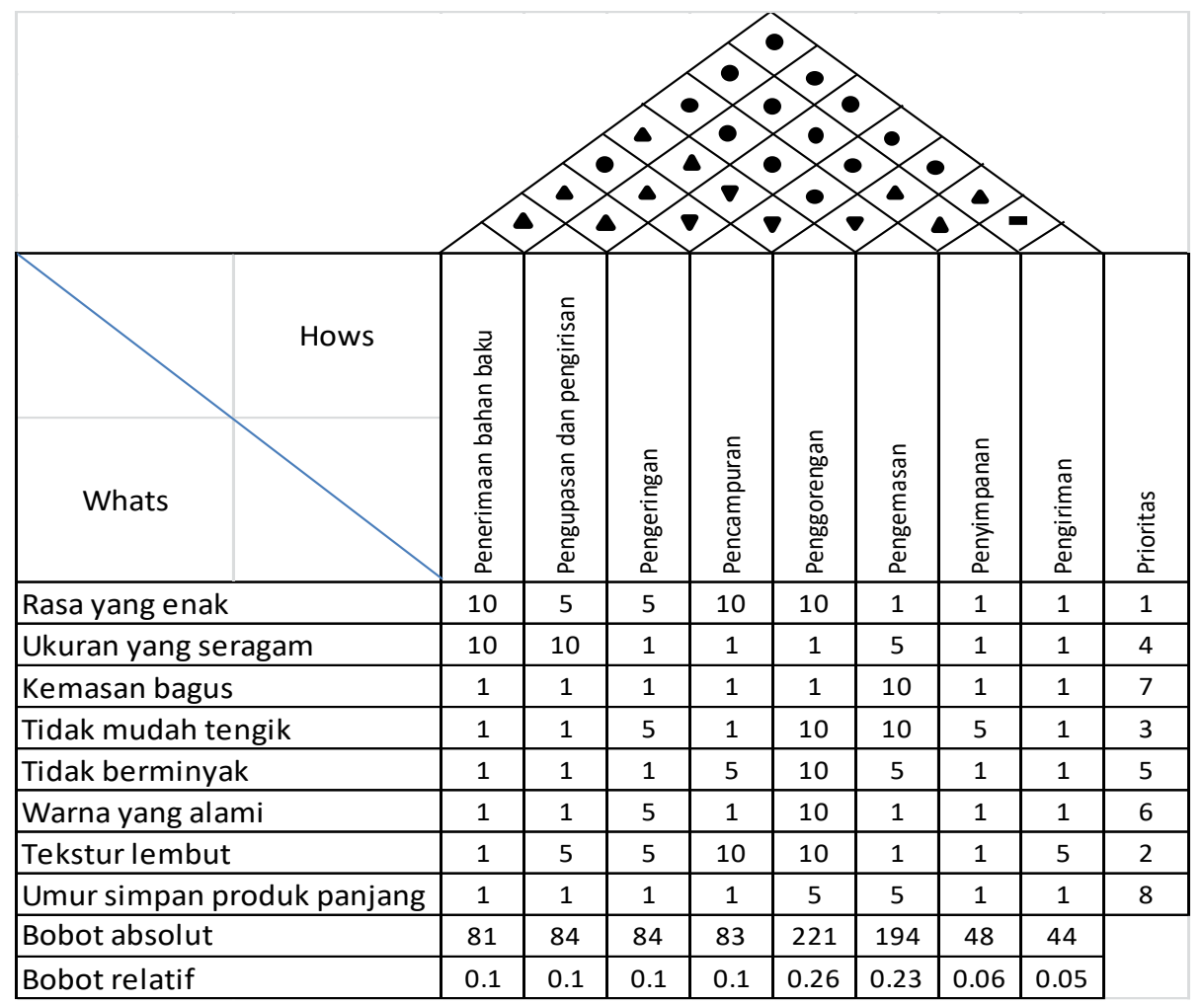

Keterangan Hubungan antara persyaratan pelanggan dengan proses :

$$
\begin{aligned}
& \text { 10= Kuat } \quad 5=\text { Sedang } \quad 1=\text { Lemah } \\
& \text { Hubungan antara proses : } \\
& \triangle \text { Mempengaruhi } \\
& \nabla \text { Saling mempengaruhi }
\end{aligned}
$$

Gambar 5. Rumah kualitas (QFD III) pisang sale dengan tahapan proses

Buah yang tingkat kematangannya kurang akan menghasilkan pisang dengan warna putih. Pisang dengan luka memar, akan menghasilkan sale dengan warna coklat kehitaman pada bekas luka memar. Menurut Prabawati et al. (2008), mutu sale pisang sangat dipengaruhi oleh tingkat kematangan buah, jenis dan mutu pisang segar yang diolah.

Tahapan proses yang sangat berpengaruh terhadap rasa sale pisang yakni pada tahapan penerimaan bahan baku seperti terlihat pada Gambar 5. Bahan baku pisang harus menggunakan buah pisang yang sempurna maka pemilihan bahan baku menjadi hal yang sangat penting agar sale pisang yang dihasilkan memiliki rasa yang memenuhi ekspektasi konsumen. Industri pengolahan biasanya mendapatkan buah pisang yang masih tua tetapi belum matang, sehingga di industri dilakukan proses pengeraman buah pisang selama 3-5 hari menggunakan karbit. Setelah buah pisang matang sempurna baru dilakukan proses pengolahan.

Tahapan proses penggorengan dan pencampuran juga berpengaruh terhadap rasa sale pisang. Diperlukan lama waktu penggorengan yang tepat agar sale pisang memiliki rasa yang enak. Jika terlalu lama digoreng maka sale pisang akan menjadi terlalu kering, sebaliknya jika terlalu sebentar maka sale pisang masih terlalu basah. Proses pencampuran yakni menambahkan tepung untuk melapisi bagian permukaan luar dan menambah rasa gurih pada sale pisang.

Atribut mutu selanjutnya yakni tekstur sale pisang yang lembut. Dikarenakan bahan baku pisang yang digunakan adalah buah pisang yang telah matang dan ditambah campuran tepung, jika dilakukan proses penggorengan yang tidak tepat maka akan menghasilkan sale pisang yang alot. Sale pisang yang alot bisa juga disebabkan dari kemasan yang mengalami kerusakan seperti ada bagian kemasan yang tertusuk sehingga udara dari luar bisa masuk dan ada bagian yang terbuka pada saat proses pengemasan. Kemasan yang rusak ini juga berpengaruh terhadap atribut mutu aroma sale pisang. Sale pisang dapat menjadi tengik diakibatkan kemasan yang rusak.

Keseragaman bentuk sale pisang juga menjadi atribut mutu sale pisang. Dengan bentuk dan ukuran yang seragam maka akan memudahkan dalam proses pengemasan, karena dapat dengan mudah disusun di dalam kemasan. Tahapan proses yang berpengaruh terhadap atribut mutu keseragaman bentuk sale pisang yakni pemilihan bahan baku dan proses pengirisan. Dibutuhkan bahan baku yang memiliki 
keseragaman bentuk sehingga pada saat proses pengirisan akan lebih memudahkan karyawan untuk mendapatkan keseragaman bentuk sale pisang.

\section{Penentuan Stretegi Peningkatan Kualitas}

Pemilihan strategi peningkatan kualitas produk dalam rantai pasok komoditas pisang menggunakan metode Analytical Hierarchy Process (AHP). Metode AHP dapat menyederhanakan kerumitan menjadi lebih sederhana melalui elemenelemen hierarki. Elemen-elemen hierarki ini selajutnya dibandingkan satu sama lain dengan teknik pairwise comparison sehingga diperoleh nilai dengan skala nominal pada setiap elemen (Bozbura dan Beskese, 2007). Skala nominal yang diperoleh merupakan nilai relatif dari semua faktor pada hierarki yang disusun dan dapat dijadikan sebagai alternatif keputusan dengan membandingkannya dengan bobot alternatif keputusan lainnya (Torfi dan Rashidi, 2011).

Dari analisa rantai pasok komoditas pisang dan atribut mutu pisang didapatkan beberapa faktor kelemahan dan aktor yang terlibat pada struktur rantai pasok. Selanjutnya menentukan apa saja indikator produk yang diharapkan dan menentukan alternatif strategi yang dapat diusulkan. Hierarki penentuan strategi alternatif peningkatan kualitas dapat dilihat pada Gambar 6.

Pada level kedua yakni aktor-aktor yang terlibat didalam struktur rantai pasok. Aktor yang terlibat diantaranya petani, pengepul, industri dan retailer. Dari hasil pembobotan, petani memiliki nilai bobot paling tinggi sebesar 0.40 dibandingkan dengan aktor yang lain. Petani memiliki peran penting dalam rantai pasok dikarenakan tugas petani sebagai penghasil bahan baku, yang mana bahan baku tersebut akan diproses dan diolah oleh industri. Industri memiliki peranan yang penting dalam rantai pasok berperan sebagai aktor yang akan melakukan proses produk mentah menjadi produk yang siap dikonsumsi. Produk yang telah selesai diproduksi selanjutnya dikirim ke retailer untuk dipasarkan ke konsumen. Aktor yang memiliki bobot terendah adalah pengepul sebesar 0.06 dimana tugas pengepul sebagai perantara antara petani dan industri. Pengepul mendapatkan buah pisang dari petani kemudian melakukan pengiriman ke industry.

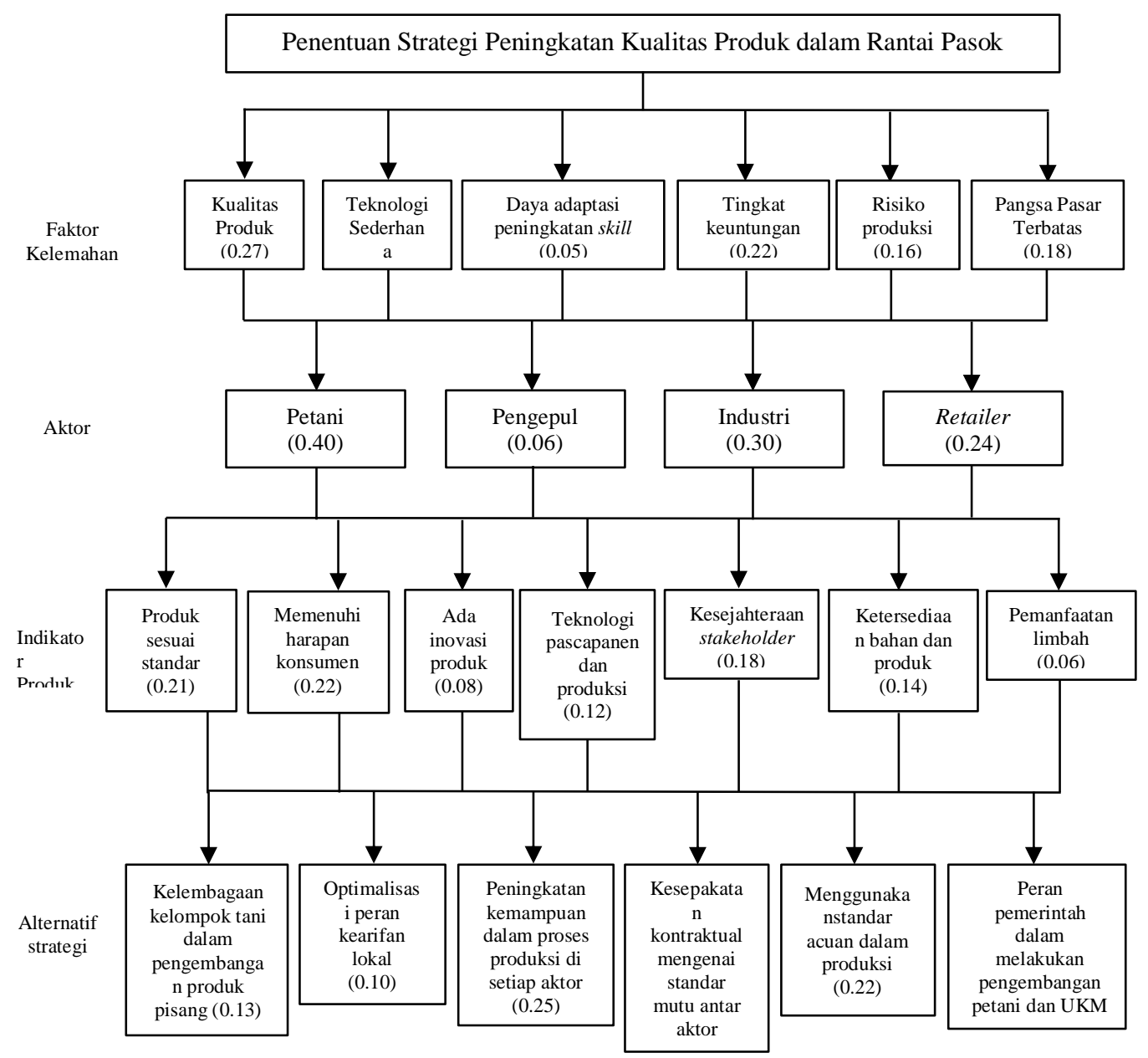

Gambar 6. Hierarki penentuan strategi peningkatan kualitas 
Dari kelemahan dan aktor yang terlibat di atas maka disusun indikator produk yang diharapkan. Didapatkan tingkat kepentingan indikator produk tertinggi yakni produk yang sesuai dengan ekspektasi konsumen dengan nilai 0,22. Dengan semakin meningkatnya kesadaran konsumen akan produk yang berkualitas dan menyehatkan, maka sangat diperlukan untuk memenuhi harapan konsumen tersebut melalui menghasilkan produk yang telah sesuai dengan standar. Selanjutnya indikator produk yang dihasilkan sesuai dengan standar dengan nilai 0,21 . Tidak hanya menghasilkan produk yang sesuai dengan harapan konsumen, industri juga harus menggunakan standar yang telah ada. Produk yang telah memenuhi standar akan memiliki kualitas yang baik dan jangkauan pasar yang lebih luas. Tentunya hal ini akan jauh lebih menguntungkan dibandingkan dengan produk yang masih memiliki kualitas rendah. Indikator produk ketiga adalah kesejahteraan para aktor yang terlibat di dalam rantai pasok dengan nilai 0,18 . Tingkat kesejahteraan juga berpengaruh terhadap cara dalam proses menghasilkan produk, dikarenakan memiliki peluang untuk melakukan proses produksi yang terbaik. Kemampuan dan kepemilikan modal akan memberikan keleluasaan kepada setiap aktor untuk mencapai produk sesuai dengan standar.

Strategi yang didapatkan dari hasil analytical hierarchy process untuk meningkatkan kualitas produk di rantai pasok pisang adalah peningkatan kemampuan dalam proses produksi pada setiap aktor, menggunakan standar dalam produksi produk, adanya kesepakatan kontrak antar aktor mengenai mutu produk, kelembagaan kelompok tani, optimalisasi kearifan lokal dan peran pemerintah dalam membantu pengembangan petani dan industri. Strategi pertama hendaknya ada peningkatan kemampuan proses produksi agar produk yang dihasilkan memiliki kualitas produk yang baik. Menurut Budiyanto (2012), komponen penting dan strategis dalam model pengembangan ketahanan pangan berbasis pisang melalui revitalisasi nilai kearifan lokal dan penguatan kelembagaan kelompok tani adalah peningkatan knowledge-skills. Peningkatan kemampuan ini dapat bekerja sama dengan pemerintahan setempat untuk melakukan sosialisasi dan pelatihan secara berkala sebagai wadah pembelajaran. Dalam proses produksi setiap aktor dapat menggunakan standar yang telah ada. Bisa menggunakan SNI (Standar Nasional Indonesia) untuk membantu memenuhi kebutuhan dalam hal melengkapi kualitas yang masih kurang. Diharapkan dengan produk yang telah memenuhi standar akan meningkatkan pangsa pasar produk menjadi lebih luas. Kelembagaan kelompok tani perlu dikembangkan dimana dengan adanya kelembagaan rantai pasokan sangat penting untuk membangun hubungan jangka panjang dengan mitra bisnis sehingga dapat meningkatkan daya saing.

\section{KESIMPULAN DAN SARAN}

\section{Kesimpulan}

Struktur rantai pasok pisang terdiri dari petani, pengepul, industri, retailer dan konsumen. Faktor mutu dominan yang berpengaruh terhadap rantai pasok komoditi pisang untuk pisang segar adalah proses perencanaan panen $(0,24)$ dan sortasi $(0,19)$, untuk sale pisang adalah proses penggorengan $(0,28)$ dan proses pengemasan $(0,20)$ dan untuk keripik pisang adalah proses penggorengan $(0,28)$ dan proses pengemasan $(0,17)$. Sedangkan untuk atribut mutu buah pisang yakni tingkat kematangan buah dan tingkat kerusakan, atribut mutu sale pisang rasa dan tekstur, atribut mutu keripik pisang rasa dan tingkat keripik pecah.

Strategi yang diusulkan untuk meningkatkan kualitas produk pada rantai pasok pisang adalah peningkatan kemampuan atau skill dalam proses produksi pada setiap aktor $(0,25)$, menggunakan standar dalam proses produksi produk $(0,22)$, memiliki kesepakatan kontrak antar aktor mengenai mutu produk yang jelas $(0,21)$, kelembagaan kelompok tani yang terstruktur $(0,13)$, optimalisasi kearifan lokal $(0,10)$ dan peran pemerintah dalam membantu pengembangan petani dan industri $(0,08)$. Dari hasi tersebut diperlukan perencanaan yang tepat dimulai dari proses panen, pengolahan dan pemasaran produk yang melibatkan seluruh stakeholder di dalam rantai pasok pisang agar menghasilkan produk yang kompetitif dan memiliki jangkauan pangsa pasar yang luas.

\section{Saran}

Adanya penelitian lebih lanjut mengenai kelembagaan pada rantai pasok komoditi pisang untuk mengintegrasikan seluruh stakeholder yang terlibat agar rantai pasok pisang lebih terstruktur, serta membahas mitigasi dan risk balancing antar stakeholder yang terlibat didalam rantai pasok pisang.

\section{DAFTAR PUSTAKA}

Agatha GP, Endaryanto T, dan Suryani A. 2020. Analisis preferensi, kepuasan dan loyalitas konsumen terhadap keripik pisang dan singkong di sentra agroindustri keripik Kota Bandar Lampung. Jurnal Ilmu-Ilmu Agribisnis. 8(1):137-144.

Ayağ Z, Samanlioglu F, dan Büyüközkan G. 2013. A fuzzy QFD approach to determine supply chain management strategies in the dairy industry. Journal Intelligent Manufacturing. 24:1111-1122.

Badan Pusat Statistik. 2019. Data Produksi dan Luas Lahan Tanaman Pisang 2011-2015. Jakarta. BPS.

Bozbura TF dan Beskese A. 2007. Prioritization of organizational capital measurement indicators 
using fuzzy AHP. International Journal Approximate Reasoning. 44(2007): 124-147

Chopra SM. 2013. Supply Chain Management: Strategy, Planning and Operation. Pearson Prentice Hall, New Jersey. United States.

Dafri M, Ratianingsih R, dan Hajar. 2018. Penanganan produksi buah pisang pasca panen melalui model pengendalian gas etilen. Jurnal Ilmiah Matematika dan Terapan. 15(2):173187.

Ding MJ, Matanda MJ, Parton KA, Jie F. 2014.Relationships between quality of information sharing and supply chain food quality in the Australian beef processing industry. The International Journal Logistics Management. 25:85-108.

He Y, Xu Q, Xu B, Wu P. 2016. Supply chain coordination in quality improvement with reference effects. Journal Operational Research Society. 67(9):1158-1168.

Ionica AC dan Leba M. 2015. QFD Integrated in New Product Development Biometric Identification System Case Study. Procedia Economics and Finance. 23:986-991.

Kozarević S dan Puška A. 2015. Corelation between implementation of supply chain, partner relationships and competitiveness. Economic Thought and Practice. 24(2):579 - 96.

Liu, Gang. 2018. The impact of supply chain relationship on food quality. Procedia Computer Science. 131:860-865

Marimin, Feifi D, Martini S, Astuti R, Suharjito, Hidayat S. 2010. Added value and performance analysis of Edamame soybean supply chain: a case study. Operations and Supply Chain Management.3:148- 163.

Marimin dan Maghfiroh N. 2011. Aplikasi teknik pengambilan keputusan dalam manajemen rantai pasok. Bogor (ID): IPB Press.

Mukhtasar, Fahrurrozi, dan Dian H. 2005. Pertumbuhan bit pisang ambon curup pada konsentrasi dan lama perendaman dalam larutan asam salisilat. Jurnal Akta Agrosia. 7(2):67-71.

Murmu SB dan Mishra HN. 2018. Post-harvest shelflife of banana and guava: Mechanisms of common degradation problems and emerging counteracting strategies. Innovative Food Science and Emerging Technologies. 49:2030

Mutakin A dan Hubeis M. 2011. Pengukuran kinerja manajemen rantai pasokan dengan SCOR model 9.0 (studi kasus di PT Indocement Tunggal Prakarsa Tbk). Jurnal Manajemen dan Organisasi. 2(3):89-103.
Novitasari R. 2013. Studi pembuatan dodol pisang. Jurnal Teknologi Pertanian. 2(1):48-56.

Nurainy F, Nurdjanah S, Nawansih O, Hidayat R. 2013. Pengaruh konsentrasi $\mathrm{CaCl}_{2}$ dan lama perendaman terhadap sifat organoleptik keripik pisang muli (Musa paradisiaca L.) dengan lama penggorengan vakum (vacuum frying). Jurnal Teknologi dan Industri Hasil Pertanian. 18(1):78-90.

Prabawati S, Suyanti, dan Setyabudi DA. 2008. Teknologi pascapanen dan teknik pengolahan buah pisang. Badan Penelitian dan Pengembangan Pertanian.

Pratiwi A, Tety E, dan Yusri J. 2015. Analisis pendapatan dan nilai tambah agroindustri tape singkong di Kota Pekanbaru. Jurnal Online Mahasiswa Fakultas Pertanian. 2(1):01-11.

Ray R.2010. Supply Chain Management for Retailing. New Delhi: Tata McGraw-Hill Publishing Company Limited.

Simin I. 2014. Analisis nilai tambah buah pisang menjadi keripik pisang pada industri rumah tangga sofie di Kota Palu. Elektronik Jurnal Agrotekbis. 2(5):510-516.

Susanti A, Arfa'i I, dan Kalsum U. 2020. Pengaruh jenis kemasan dan masa simpan terhadap karakteristik keripik pisang kapok (Musa paradisiaca L.). Exact Papers in Compilation. 2(1):199-204.

Torfi F dan Rashidi A. 2011. Selection of project managers in construction firms using Analytic Hierarchy Process (AHP) and Fuzzy TOPSIS: A Case Study. Journal Construction in Ceveloping Countries. 16(1): 69-89.

Vorst JG. 2006. Chapter 2: Performance measurement in agri-food supply chain networks, An Overview.Quantifying the agrifood supply chain.13-24.

Widiastuti W. 2011. Peningkatan Daya Saing Pisang Ambon Curup melalui Strategi Branding. Jurnal Penelitian Ilmu Sosial dan Budaya. 8(2). 193-203.

Wiharja YP dan Harjoko A. 2014. Pemrosesan citra digital untuk klasifikasi mutu buah pisang menggunakan jaringan saraf tiruan. Indonesian Journal Electronics and Instrumentations Systems. 4(1):57-68.

Zaim S, Sevkli M, Camgöz-Akdağ H, Demirel OF, Yesim Yayla A, Delen D. 2014. Use of ANP weighted crisp and fuzzy QFD for product development. Expert Systems with Applications. 41(9):4464-4474. 